\title{
Influenza 2009: experience, lessons and pending issues
}

\author{
José Luis Sandoval-Gutiérrez
}

Critical Areas, Instituto Nacional de Enfermedades Respiratorias Ismael Cosío Villegas, Ciudad de México, Mexico

Córdova-Villalobos et al. ${ }^{1}$ present an interesting work where all actions that were carried out to confront the respiratory influenza pandemic of 2009 that had its epicenter in the Mexican Republic are described. The balance is positive, and the country was an international example of adequate management and attitude in the face of this new, dawn of century presentation.

It's important mentioning that the measures of contention, such as closing public places, schools, working areas regarded as non-essential, such as restaurants and meeting places, movie theaters, theater venues, and sports stadiums, which were initially criticized, resulted in an important decrease in the number of contagions, especially in Mexico City, where the metropolitan area exceeds a population of 20 million².

Our nation needs to be self-sufficient in the production of the vaccine, to be able to achieve a larger coverage on its application, since our entire population exceeds 129 million people ${ }^{3}$.

National intensive therapies in general, though not in particular, have been unable to reduce mortality to desirable rates that are comparable to those of North America ${ }^{4}$.

It is necessary that health-related state laboratories opportunely report on the appearance of new viruses or on the trend toward the predominance of a particular serotype in the weekly follow-up, to be able to take relevant measures at different health units. In general, it occurs that patients start arriving abruptly and massively to health areas, and then the laboratories are pressed to inform whether there is a special presentation accounting for the event.

There are several pending issues to solve in the future, but it is relevant mentioning that the decision-makers who were present in the pandemic, and who are involved in the authorship of the article in question, rose to the occasion and achieved a result that is worthy of recognition, to the benefit of our country's and global respiratory health.

\section{References}

1. Córdova-Villalobos JA, Macías AE, Hernández-Ávila M, et al. La pandemia de 2009 en México: Experiencia y lecciones acerca de las políticas nacionales de preparación contra la influenza estacional y epidémica. Gac Med Mex. 2017;153:102-10.

2. Zona metropolitana del valle de México. (Consultado el 27 de junio de 2017.) Disponible en: Https://es.wikipedia.org/wiki/Zona_metropolitana_ del_valle_de_M\%C3\%A9xico.

3. México es el décimo país más poblado del mundo: ONU. (Consultado el 27 de junio de 2017.) Disponible en: http://www.excelsior.com.mx/ nacional/2017/06/21/1171150.

4. Domínguez-Cherit G, De la Torre A, Rishu A, et al. Influenza A (H1N$1 \mathrm{pdm09})$-related critical illness and mortality in Mexico and Canada, 2014. Crit Care Med. 2016;44:1861-70.
Dear Mr. Editor:

On behalf of the authors of our review ${ }^{1}$ on the 2009 influenza pandemic in Mexico, I thank for the opinion expressed in the above letter to the editor. Therein, the successful actions taken by Mexico in reaction to the pandemic are established, but also the lessons learnt about aspects we have to refine in the future, namely:

- A plan to establish social physical distancing measures in case of new epidemics. This point is essential in order for panic and explosive spread of the epidemic to be prevented, although

\section{Correspondence:}

José Luis Sandoval-Gutiérrez

Tlalpan, 4502

Col. Sección. XV

C.P. 06170, Ciudad de México, México

E-mail: sandovalgutierrez@gmail.com
Date of modified version reception: 28-06-2017

Date of acceptance: 03-07-2017

DOI: 10.24875/GMM.17003535

Gac Med Mex. 2017;153:477-478

Contents available at PubMed www.gacetamedicademexico.com 
it should be adapted to each region's situation to minimize its economic impact.

- There should be the necessary sovereignty in the production of vaccines. This is an important point since producer countries are known to look after their needs first, before allowing their surplus to be commercialized. Mexico has suffered this problem in recent years, not only with influenza vaccines but also even with those associated with childhood immunization schedules.

- There is a need for national capabilities for intensive care and hospital reconversion to be quantitatively and qualitatively increased. This point is determinant to prevent hospitals' dysfunction and public healthcare system collapse. We should follow the example set by the Instituto Nacional de Ciencias Médicas y Nutrición Salvador Zubirán, which already has a hospital reconversion department for disasters available.

- Local and regional services should provide diagnostic support. This point is determinant for informing clinicians about circulating viruses' characteristics, as well as on the intensity of outbreaks, including the detection of new pathogens with epidemic potential. For this reason, Public Health State Laboratories were supplied since 2009 with modern equipment that allows accurate identification of the different known influenza viruses, and even others.

The above points are just an example of many things that have to be done to be prepared for the next pandemic, which inevitably will occur. Our health system has remained on alert, but we must update our preparation plan to have a friendly master document that sets the path that has to be followed during interpandemic (in which we currently are), pandemic, and post-pandemic phases. The US Department of Health and Human Services recently published a similar document $^{2}$. We should also update our medications and materials strategic reserves to confront an epidemic, and avoid bargaining them in market situations that make their acquisition impossible.

\section{References}

1. Córdova-Villalobos JA, Macías AE, Hernández-Ávila M, et al. La pandemia de 2009 en México: experiencia y lecciones acerca de las políticas nacionales de preparación contra la influenza estacional y epidémica. Gac Med Mex. 2017;153:102-10.

2. U.S. Department of Health and Human Services. Pandemic Influenza Plan. 2017 UPDATE. (Consultado el 30 de junio de 2017.) Disponible en: https://www.cdc.gov/flu/pandemic-resources/pdf/pan-flu-report2017v2.pdf.

José Ángel Córdova-Villalobos

Universidad de Guanajuato

C.P. 37000 , León, Gto., México

E-mail: jangelcordova.villalobos@gmail.com 